\title{
ПРОФІЛАКТИКА ТА ЛІКУВАННЯ ТОКСИЧНОГО ГЕПАТИТУ Й ЕНДОГЕННОЇ ІНТОКСИКАЦІЇ У ХВОРИХ ІЗ ЛІМФОПРОЛІФЕРАТИВНИМИ ЗАХВОРЮВАННЯМИ
}

\author{
๑о. Є. Самогальська, 3. П. Мандзій \\ Тернопільський національний медичний університет імені І. Я. Горбачевського МОЗ України
}

РЕЗЮмЕ. За даними сучасних епідеміологічних і статистичних досліджень, останнім часом в Україні значно зросла частота захворюваності на хронічну патологію печінки. Перебіг захворювання супроводжується виснаженням системи антиоксидантного захисту, на тлі чого розвивається хронічна інтоксикація з метаболічними порушеннями, які негативно впливають на функціональний стан печінки.

Мета - вивчити ефективність комбінованого гепатопротектора «Гепаргін» у складі комплексної терапії хворих із гемобластозами.

Матеріал і методи. Під нашим спостереженням перебували 42 хворих із лімфопроліферативними захворюваннями (6 - із гострими лімфобластними лейкеміями; 16 - із хронічними лімфоїдними лейкеміями; 9 - із неходжкінськими лімфомами: 7 - із неходжкінськими лімфомами з малих лімфоцитів, а 5 хворих - із неходжкінськими лімфомами з великих гранулярних клітин). Вік хворих становив від 34 до 68 років. Середня тривалість захворювання становила 4-7 років. Усім хворим проводили ультразвукове дослідження органів черевної порожнини (УзД ОчП) та визначали біохімічні показники функції печінки, а саме аланінамінотрансфаразу, аспартатамінотрансферазу, білірубін, лужну фосфатазу, тимолову та сулемові проби, ядерний індекс інтоксикації.

Результати. Хворі скаржилися на загальну слабість, нездужання, тяжкість у нижніх кінцівках, запаморочення. Їх турбували тяжкість та відчуття розпирання у правому підребер'ї, нудота. Інколи відмічали жовтяничність шкіри та слизових оболонок. При УзД ОЧП у 22 хворих спостерігали збільшення розмірів печінки. У середньому печінка була збільшена як за рахунок правої частки, так і лівої. У 19 хворих спостерігали підвищення АЛТ та АСТ, у 11 хворих також відмічали підвищення білірубіну за рахунок непрямої фракції. Активність процесу переважно відповідала середньому (58,7 \%) та вираженому (21,3 \%) ступеням. У процесі отримання як моно-, так і поліхіміотерапії, активність вираження токсичного впливу на стан функції гепатоцитів посилювалася, на що вказували печінкові проби. Так, показники АЛТ та АСТ підвищувалися, також спостерігалось підвищення лужної фосфатази, білірубіну за рахунок непрямої фракції. У 5 хворих із гемобластозами спостерігали жовтяничність шкіри та склер.

Висновки. На основі комплексного лікування із застосуванням препарату «Гепаргін» відмічалась позитивна динаміка клінічного перебігу основного захворювання, яка проявлалася покращенням самопочуття хворого, загального стану, зникненням тяжкості в правому підребер'ї.

Аналіз показників функціональних проб печінки під впливом терапії показав зниження активності запального процесу в гепатоцитах, на що вказували АЛТ, АСТ, білірубін, лужна фосфатаза, ядерний індекс інтоксикації.

У хворих із мінімальною та середньою активністю ці показники поверталися до нормальних величин, а у хворих із вираженою активністю - зменшувалися. Також встановлений позитивний вплив препарату на білковий метаболізм, про що свідчить підвищення загального білка сироватки крові.

КлючовІ СлОВА: гепаргін; лейкемії; лікування; токсичний гепатит; ендогенна інтоксикація.

Вступ. За даними сучасних епідеміологічних досліджень, останнім часом в Україні значно зросла частота захворюваності на хронічну патологію печінки. Перебіг захворювання супроводжується патологією системи антиоксидантного захисту, на тлі чого розвивається хронічна інтоксикація з метаболічними порушеннями, які негативно впливають на функціональний стан печінки.

Відомо, що, незалежно від етіологічного чинника (хімічні шкідливі речовини, алкоголь, радіація тощо), в патогенетичному плані характерним $\epsilon$ ураження мембран гепатоцитів, i, як наслідок, порушення функції печінки, насамперед білковосинтезувальнної та детоксикаційної. Окрім того, ушкодження печінки може бути наслідком побічної дії препаратів, які застосовуються при основній патології. А це прийом антибіотиків, імунодепресантів, глюкокортикоїдів, НПЗП та інших лікарських засобів. Сьогодні значну роль у формуванні уражень функції печінки відіграють токсичні фактори. Важливим фактором впливу на функцію печінки є використання сучасних клінічних протоколів згідно зі стандартами терапії гемобластозів. Підвищення ефективності лікування досягнуто завдяки застосуванню нових препаратів та інтенсифікації режимів хіміотерапії. Проте негативною стороною поліхіміотерапії (ПХТ) є побічна дія протипухлинних лікарських засобів. За даними клінічних досліджень встановлено, що медикаментозне ураження печінки становить близько 10 \% усіх побічних реакцій, пов'язаних із застосуванням цитостатичних препаратів [1, 5, 6, 10, 12]. Насправді гепатотоксичність розвивається, мабуть, частіше, ніж свідчить офіційна медична статистика, оскільки печінка $є$ однією з основних ланок біотрансформації цитостатиків [2, 4].

Морфологічні зміни при токсичних ураженнях печінки можуть мати практично будь-який ха- 
Огляди літератури, оригінальні дослідження, погляд на проблему, випадок з практики, короткі повідомлення рактер, у тому числі некроз, стеатоз, фіброз, холестаз та пошкодження судин [1]. Гепатотоксичність під час ХT не завжди спричинена дією протипухлинних препаратів. Необхідно розглядати також можливість токсичної дії антибіотиків, анальгетиків, протиблювотних засобів або інших ліків $[2,3]$.

Однією з основних причин порушень гепатоцитів у хворих онкологічного та онкогематологічного профілю $є$ синдром ендотоксикозу, який розвивається в результаті пухлинної інтоксикації, бактерійних та вірусних інфекцій, що приєднуються, а також унаслідок масивного лізису пухлинної тканини у відповідь на введення цитостатиків [14].

Відомо, що печінка є органом, де відбувається біотрансформація більшості цитостатиків [14]. У літературі наведено значну кількість даних, що демонструють участь монооксигеназ печінки в їх метаболізмі. Виснаження системи цитохрому P450, яка бере участь у метаболізмі медикаментів, може призвести до зниження виведення токсичних компонентів, що надходять в організм, викликати їх накопичення в органах та тканинах, порушити знешкодження ендогенних продуктів метаболізму або спричинити утворення вторинних, які можуть бути ще токсичнішими. Зниження ефективності цієї ферментативної системи призводить до підвищення токсичності цитостатичних препаратів [2, 3, $11,12]$. Так, за даними деяких досліджень, установлено, що цитостатичні препарати можуть у декілька разів підсилити чутливість гепатоцитів до ендотоксину [2]. Крім того, в роботах більшості дослідників доведено, що, оскільки виведення шкідливих для печінки речовин у цих умовах досить проблематичне, протипухлинні препарати можуть спричинити кумулятивну токсичну дію останніх на її функціональний стан $[9,13,15]$.

При застосуванні протипухлинних препаратів досить часто розвивається їх гепатотоксичний ефект, який проявляється досить широким спектром клініко-морфологічних варіантів патології печінки [4]. Зокрема, при дослідженні доксорубіцину виявили, що разом із ураженням печінки за типом гострого гепатиту може розвиватися печінковий фіброз різного ступеня. Прояв токсичності 6-меркаптопурину характеризується некрозом й ожирінням гепатоцитів, формуванням фіброзу портальних трактів, холестатичним ураженням, розвитком печінкової недостатності. Токсичні гепатити можуть розвиватися внаслідок прийому бендамустину, циклофосфаміду (ендоксану), L-аспарагінази, ідарубіцину, а також прийому сучасних протипухлинних препаратів - талідоміду, леналідоміду [7]. У гематології застосовують також імунодепресанти, зокрема циклоспорин, які викликають токсичне ураження печінки. Поєднання різних

препаратів може призводити до потенціювання їх гепатотоксичності. Так, дія на печінку 6-меркаптопурину посилюється при паралельному застосуванні доксорубіцину $[12,17]$. Згідно зі стандартами лікування, протоколи включають кілька препаратів, тобто, поліхіміотерапію (ПХТ), яка має ще більший токсичний вплив на функцію печінки. Тривале лікування цитостатичними препаратами може спричинити портальну гіпертензію внаслідок формування вираженого фіброзу.

У пацієнтів з онкопатологією можливе пострадіаційне ураження печінки, яке в гострий період може характеризуватися підвищенням рівня трансаміназ, гіпербілірубінемією (жовтяницею) та асцитом. Паралельне застосування доксорубіцину та вінкристину потенціює променеве ураження печінки. Одним із віддалених наслідків опромінення $є$ фіброз печінки. У зв'язку з широким застосуванням цитостатичних та гормональних препаратів, які мають виражену імуносупресивну дію, для лікування пацієнтів із злоякісними захворюваннями відзначають високу розповсюдженість інфекційних захворювань у хворих цієї категорії. Отже, як токсичні гепатити так і виникнення ендогенної інтоксикації у цих пацієнтів також можуть бути зумовлені широким спектром інфекційних агентів: неспецифічними ураженнями в рамках генералізованних інфекцій, абсцесами печінки, грибковими захворюваннями та вірусними гепатитами, зокрема, спричиненими цитомегаловірусами, вірусами простого й оперізувального герпесу, аденовірусами [4].

Для оцінки ступеня і глибини пошкодження гепатоцитів зазвичай застосовують клініко-біохімічні дослідження цілісності печінкової клітини, її екскреторної активності, холестазу, функціональної здатності печінки. Враховуючи, що морфологічне дослідження печінки ми не проводили, то аналіз біохімічних показників дозволяє уточнити рівень і провідний механізм розвитку порушень функції печінки і виявлення ступеня ендогенної інтоксикації. У клінічній практиці саме зміна лабораторних показників часто $є$ відправним пунктом для проведення диференційної діагностики, визначення форми патології печінки та призначення патогенетичної терапії. На підставі лабораторних показників можна зробити висновок про тяжкість патологічного процесу в печінці і проявів ендогенної інтоксикації, прогнозувати перебіг захворювання, а також оцінювати ефективність терапії, що проводиться.

Більшості пацієнтів призначають патогенетичне і симптоматичне лікування для запобігання і лікування токсичного ураження печінки та проявів інтоксикації на ґрунті проведення цитостатичного лікування $[13,16]$. 
Огляди літератури, оригінальні дослідження, погляд на проблему, випадок з практики, короткі повідомлення

До таких препаратів належить комплексний препарат «Гепаргін», який містить аргініну цитрату нейтрального 1000 мг, бетаїну гідрохлориду 500 мг та іони цитрату. Завдяки своєму збалансованому складу препарат здатний впливати одразу на декілька патогенетичних ланок захворювання печінки.

Так, аргінін - амінокислота, що належить до незамінних амінокислот, тобто частково синтезується в організмі, але в кількості, що не покриває добову потребу людини, тому аргінін повинен регулярно надходити з їжею. При різних захворюваннях, дефіциті в раціоні білка, а також із віком синтез аргініну в організмі різко знижується.

При дефіциті аргініну насамперед страждає система, що відповідає за виведення аміаку з організму і його знешкодження. В організмі людини аміак $\epsilon$ токсичною речовиною, тому за нормальних умов він метаболізується в сечовину. При хронічних захворюваннях, вірусних інфекціях, отруєннях порушується перетворення аміаку на сечовину. Цикл сечовини - найважливіший шлях знешкодження аміаку, при його неспроможності страждає весь організм і, в першу чергу, печінка та нирки, тому що висока концентрація сечовини призводить до їх пошкодження. Аргінін є субстратом для синтезу сечовини в печінці. Аргінін сприяє знешкодженню аміаку шляхом активізації його перетворення на нетоксичну сечовину і прискоренню її виведення нирками з організму, а також сприяє підтриманню оптимального азотистого балансу в організмі, сприяє виведенню кінцевого азоту, знижує утворення шкідливих для клітин печінки вільних радикалів, чим посилює детоксикаційну функцію печінки.

Аргінін $\epsilon$ основою для ферменту NO-синтетази, яка виступає в ролі каталізатора при синтезі оксиду азоту в клітинах ендотеліальної оболонки судин. Посилене утворення NO призводить до дилатації периферійних судин і зниження загального периферійного опору, що сприяє зниженню артеріального тиску та зменшенню кисневого голодування різних тканин, насамперед міокардіальної, а також покращує кровообіг у периферійних судинах і доставку кисню до головного мозку. Аргінін пригнічує утворення ендотеліїну речовини, що має потужну вазоконстрикторну дію та $\epsilon$ стимулятором ділення гладком'язових клітин стінки судин.

Аргінін бере участь у комунікації між нервовими клітинами, сприяє синаптичній пластичності і поліпшенню пам' яті, а також $є$ медіатором, що обумовлює релаксацію гладком'язових клітин шлунка, кишечника, сечового міхура, матки.

Бетаїн - ліпотропна речовина, яка є осмопротектором та донором метильних груп. Як осмо- протектор, бетаїн захищає клітини, білки і ферменти від впливу навколишнього середовища (вірусні інфекції, стрес, інтоксикація). В якості донора метильних груп бетаїн бере участь у метіоніновому циклі, головним чином в печінці та нирках. Недостатній печінковий метаболізм жирів призводить до стеатозу печінки (накопичення жиру в печінці) та подальшого розвитку дисліпідемії. Ці зміни в обміні речовин можуть сприяти розвитку захворювань серця, мозку, печінки і судин. Недостатність метильних груп призводить до підвищеної концентрації гомоцистеїну в плазмі людини, що може призвести до виникнення тромбоемболії. При перетворенні гомоцистеїну в метіонін бетаїн може функціонувати як альтернативний донор метильних груп. Завдяки цьому бетаїн може заміщати дефекти в реакціях метилювання, що викликані порушенням функціонування фолатного циклу і нестачею вітаміну $\mathrm{B}_{12}$. Бетаїн збільшує витривалість під час фізичних навантажень, працездатність, сприяє зменшенню загальної слабкості і втоми, забезпечує приплив сил і енергії. Бетаїн $є$ важливою речовиною для профілактики хронічних захворювань.

Іони цитрату, що містяться в Гепаргіні, сприяють зменшенню ацидозу та диспептичних проявів (нудота, відчуття тяжкості в шлунку, метеоризм), які часто спостерігаються при захворюваннях печінки та інтоксикації.

Дорослим призначають по 1-3 флакони на добу після прийому їжі, вміст одного флакона потрібно розвести в половині склянки води та випити [16].

Отже, складові комплексного препарату «Гепаргін» забезпечують відповідний захист і відновлюють нормальне функціонування клітин печінки, вбудовуючись у пошкоджені клітинні мембрани гепатоцитів, а також позитивно впливають на ліпідний обмін організму. Окрім того, «Гепаргін» бере участь у здійсненні трансмембранного транспорту в мітохондріях високомолекулярних жирних кислот і здатний покращувати енергетичний баланс в організмі та збільшувати його витривалість, підвищувати засвоєння протеїнів, вітамінів, вуглеводів, зберігати запас глікогену в печінці, стимулювати кровотворення та виділення кисню еритроцитами, забезпечуючи захисну дію в умовах гіпоксії.

Отже, «Гепаргін» нормалізує ліпідний та вуглеводний обмін, має протинабрякову та мембраностабілізувальну дії, покращує детоксикаційну функцію печінки, чинить антиоксидантний, антигіпоксичний та репаративний ефект. Такий широкий спектр фармакологічної дії препарату визначив можливість використання його в комплексному лікуванні хворих із гемобластозами як для 
Огляди літератури, оригінальні дослідження, погляд на проблему, випадок з практики, короткі повідомлення лікування токсичних гепатитів, їх профілактики, так і для лікування і запобігання виникненню гіпоксичних станів в організмі.

Мета - вивчити ефективність комбінованого препарату «Гепаргін» у складі комплексної терапії хворих із лімфопроліферативними захворюваннями.

Матеріал і методи дослідження. Під нашим спостереженням перебували 42 хворих із лімфопроліферативними захворюваннями (6 - із гострими лімфобластними лейкеміями; 16 - із хронічними лімфоїдними лейкеміями; 9 - із неходжкінськими лімфомами: 7 - із неходжкінськими лімфомами з малих лімфоцитів, 5 - із неходжкінськими лімфомами з великих гранулярних клітин). Вік хворих був від 34 до 68 років. Середня тривалість захворювання становила 4-7 років. Усім хворим проводили ультразвукове дослідження органів черевної порожнини (УЗД ОЧП) та визначали біохімічні показники функції печінки, а саме рівні аланінамінотрансфарази, аспартатамінотрансферази, білірубіну, лужної фосфатази, тимолову та сулемові проби. Рівень ендогенної інтоксикації визначали за ядерним індексом інтоксикації (ЯІІ) за Даштаянц Г. А.

Критерієм включення пацієнтів до дослідження були зміни функціональних печінкових проб, які були пов'язані з початком перебігу основного захворювання та його лікування. Лікувальний комплекс усіх пацієнтів включав препарати базисної терапії. А це прийом поліхіміотерапії згідно з протоколами стандартів лікування, призначення гормональних препаратів, а саме преднізолону, з подальшим зниженням його дози. Поряд із базисною терапією пацієнти отримували комплексний препарат «Гепаргін», який призначали по 1 флакону 2 рази на добу після їди 7 днів до призначення хіміотерапії та 3-4 тижні після лікування в амбулаторних умовах. Через місяць усім хворим проводили контрольне обстеження гепатобіліарної системи та визначали ЯІІ.

Результати й обговорення. Окрім скарг 3 приводу основного захворювання (а це загальна слабість, нездужання, тяжкість у нижніх кінцівках, запаморочення) хворих турбували тяжкість та відчуття розпирання у правому підребер'ї, нудота. Інколи відмічали жовтяничність шкіри та слизових оболонок. При УЗД ОЧП у 24 хворих спостерігали збільшення розмірів печінки і селезінки. У середньому печінка була збільшена як за рахунок правої частки, так і лівої. У 21 хворого спостерігали підвищення АЛТ та АСТ, у 11 хворих також відмічали підвищення білірубіну за рахунок непрямої фракції. Активність процесу переважно відповідала середньому $(59,7$ \%) та вираженому (22,3 \%) ступеням. У процесі отримання як моно-, так і поліхіміотерапії, активність вираження токсичного впливу на стан функції гепатоцитів посилювалася, на що вказували печінкові проби. Показники АЛТ та АСТ підвищувалися, також спостерігали підвищення рівня лужної фосфатази, білірубіну за рахунок непрямої фракції. У 5 хворих з гемобластозами спостерігали жовтяничність шкіри та склер.

При обрахунках ЯІІ відмічали його підвищення у 17 хворих, що відповідало середньому ступеню тяжкості, у 21 хворого - легкому ступеню, а у 4 хворих відмічали підвищення ЯІІ до тяжкого ступеня.

На основі комплексного лікування із застосуванням препарату «Гепаргін» відмічали позитивну динаміку клінічного перебігу основного захворювання, яка проявлялася покращенням самопочуття хворого, а саме зменшенням нудоти, загальної слабості, запаморочення, покращанням загального стану, зникненням тяжкості в правому підребер'ї та зменшенням тяжкості в лівому підребер'ї. Аналіз показників функціональних проб печінки під впливом терапії показав зниження активності запального процесу в гепатоцитах, а також зменшення проявів ендогенної інтоксикації, на що вказували показники АлТ, АСТ, білірубіну, лужної фосфатази та ЯІІ (табл. 1).

Таблиця 1. Показники функції гепатоцитів та рівня ендогенної інтоксикації до лікування цитостатиками та після отримання поліхіміотерапії і комбінованого препарату «Гепаргін».

\begin{tabular}{|l|c|c|c|c|}
\hline \multicolumn{1}{|c|}{ Показники } & Норма & $\begin{array}{c}\text { До лікування } \\
\text { цитостатиками }\end{array}$ & $\begin{array}{c}\text { Після лікування } \\
\text { цитостатиками }\end{array}$ & $\begin{array}{c}\text { Після прийому } \\
\text { «Гепаргін» }\end{array}$ \\
\hline Загальний білірубін & $<18,81$ мкмоль/л & $19,01 \pm 0,10$ & $28,02 \pm 0,10$ & $17,03 \pm 0,10$ \\
\hline АлАТ & $<40,00$ & $54,01 \pm 0,10$ & $70,01 \pm 0,10$ & $27,00 \pm 0,10$ \\
\hline АсАТ & $<40,00$ & $48,02 \pm 0,10$ & $59,01 \pm 0,10$ & $41,01 \pm 0,10$ \\
\hline ЛФ & $35-129$ & $1310,01 \pm 0,10$ & $140,01 \pm 0,10$ & $87,01 \pm 0,10$ \\
\hline Загальний білок & $65-85$ мкмоль/л & $65,02 \pm 0,20$ & $55,02 \pm 0,10$ & $69,02 \pm 0,10$ \\
\hline яІІ & $0,05-0,08$ & $0,65 \pm 0,02$ & $0,73 \pm 0,03$ & $0,08 \pm 0,01$ \\
\hline
\end{tabular}

У хворих із мінімальною та середньою активністю ці показники поверталися до нормальних ве- личин, а у хворих із вираженою активністю - зменшувались. Також установлено позитивний вплив 
Огляди літератури, оригінальні дослідження, погляд на проблему, випадок з практики, короткі повідомлення препарату на білковий метаболізм, про що свідчить підвищення загального білка сироватки крові.

Висновки. 1. У комплексному лікуванні хворих із лімфопроліферативними захворюваннями обґрунтованим $\epsilon$ застосування комбінованого препарату «Гепаргін», який має широкий спектр фармакологічної дії, а саме детоксикаційні, антигіпоксійні, протизапальні, метаболічні, гепатопротекторні ефекти його компонентів.

2. Такий широкий спектр фармакологічної дії препарату визначив можливість використання його у комплексному лікуванні хворих із лімфопроліферативними захворюваннями, як для лікування токсичних гепатитів та ендогенної інтоксикації, так і для їх профілактики.

3. У пацієнтів, які отримували терапію «Гепаргіном» на ґрунті цитостатичної терапії, виявлено статистично достовірну нормалізацію біохімічних показників, які характеризували стан функції печінки і ендогенної інтоксикації. Корекція стану печінки і ендогенної інтоксикації дозволила провести в усіх хворих заплановане цитостатичне лікування. Після закінчення курсу моно- чи поліхіміотерапії в 89 \% пацієнтів не виявлено по-

\section{ЛІТЕРАТУРА}

1. Болезни печени и желчевыводящих путей / Под ред. В. Т. Ивашкина. - М. : ООО «Издательский дом «М-Вести», 2002. - 432 с.

2. Городецкий В. М. Осложнения противоопухолевой терапии / В. М. Городецкий // Гематология и трансфузиология. - 1998. - № 1. - С. 11-15.

3. Кан В. К. Холестаз: новое в патогенезе, диагностике и лечении / В. К. Кан // Российский журнал гастроэнтерологии, гепатологии. - 1997. - Т. 7, № 3. - С. 25-29.

4. Клиническая онкогематология / Под ред. М. А. Волковой. - М. : Медицина, 2001. - 572 с.

5. Майер К. П. Гепатит и последствия гепатита / К. П. Майер / Пер. с нем. - М. : ГЭОТАР-Медиа, 2004. 424 c.

6. Acute hepatoxicity with intermediate-dose methotrexate inn children with leukemia and non-Hodgkin's lymphoma / P. Exadaktylos, T. Reiss, R. Schobess [et al.] // Klin. Padiatr. - 1994. - Vol. 206 (4). - P. 315-318.

7. Fowler R. Thalidomide-associated hepatitis: a case report / R. Fowler, K. Imrie // Am. J. Hematol. - 2001. Vol. 66 (4). - P. 300-302.

8. Frezza M. The use of S-adenosyl-L-methiorline in the treatment of cholestatic disorders: a meta-analysis of clinical trials / M. Frezza, M. Terpin // Drug Invest. - 1992. Vol. 4 (Suppl. 4). - P. 101-108.

9. Direct cell-to-cell contact between Kupfer cells and hepatocytes augments endotoxin-induced hepatic injury / K. H. Hoebe, R. F. Witkamp, J. Fink-Gremmels [et al.] // Am. J. Physiol. Gastrointest. Liver Physiol. - 2001. - Vol. 280 (4). P. G720-728.

гіршання функції печінки, про що свідчать показники печінкових проб.

4. У результаті проведеного дослідження встановлено, що в пацієнтів із онкогематологічними захворюваннями для запобігання гепатотоксичності й проявам ендогенної інтоксикації на тлі проведення хіміотерапії і для зменшення вираження вже розвинутих проявів гепатопатії та інтоксикації необхідне долучення до протоколу лікування препаратів патогенетичної терапії.

5. Захисна дія комбінованого препарату «Гепаргін» дозволить зменшити кількість вимушених зміну протоколахполіхіміотерапії, пов' язаних із ураженням печінки, у більшості хворих дозволяє поліпшити переносимість моно- та поліхіміотерапії, підвищити якість життя пацієнтів у період лікування і реабілітації.

Перспективи подальших досліджень. у процесі дослідження вдалося виявити основні причини погіршення стану здоров'я хворих із лімфопроліферативними захворюваннями після отримання ПХТ. Визначення ЯІІ у пацієнтів дає можливість прогнозувати перебіг захворювання і подальший вплив ПХТ на якість їх життя.
10. Jansen P. L. Intrahepatic cholestasis and biliary cirrhosis associated with extrahepatic Hodgkin's disease / P. L. Jansen, H. Van der Lelie // Neth. J. Med. - 1994. Vol. 44 (3). - P. 99-102.

11. Glutathione metabolism and phisiological functions / In: J. Vina Ed. - Boston, 1990. - 378 p.

12. Levis J. H. Methotrexat-induced chronic liver injury: guidelines for detection and prevention / J. H. Levis, E. Schiff // Am. J. Gastroenterol. - 1998. - Vol. 83 (12). P. 1337-1345.

13. Laidlaw S. T. Fatal hepatotoxicity associated with 6-mercaptopurine therapy / S. T. Laidlaw, J. T. Reilly, S. K. Suarna // Postgrad. Med. J. - 1995. - Vol. 71 (840). - P. 639.

14. S-adenosylmethionine (AdoMet) supplementation for treatment of chemotherapy-induced liver injury / D. Santini, B. Vincenzi, C. Massacesi [et al.] // Anticancer Res. 2003. - Vol. 23 (6D). - P. 5173-5179.

15. Glutathione-S-transferase enzyme expression in hematopoietic cell lines implies a differential protective role for $\mathrm{TI}$, and $\mathrm{Al}$ isoenzymes in erythroid and for $\mathrm{MI}$ in lymphoid lineages / L. Wang, J. Gloves, M. Hepburn, D. T. Bowen // Haematologica. - 2000. - Vol. 85 (6). - P. 573-579.

16. Шано В. П. Синдром эндогенной интоксикации / В. П. Шано, Е. А. Кучер // Острые и неотложные состояния в практике врача. - 2011. - № 1 (25). - С. 35-41.

17. Вікова динаміка змін стану мінеральної щільності кісткової тканини в хворих на хронічну лімфоїдну лейкемію / І. В. Жулкевич, Р. Й. Вибирана, К. В. Баранніков // Вісник наукових досліджень. - 2013. - № 1. C. $47-50$. 
Огляди літератури, оригінальні дослідження, погляд на проблему, випадок з практики, короткі повідомлення REFERENCES

1. Ivashkin, V.T. (Ed.). (2002). Bolezni pecheni izhelchevyvodyashchikh putey [Diseases of the liver and biliary tract]. Moscow: OOO «lzdatelskiy dom «M-Vesti» [in Russian].

2. Gorodetskiy, V.M. (1998). Oslozhneniya protivoopukholevoy terapii [Complications of antineoplastic therapy]. Gematologiya $i$ transfuziologiya - Hematology and Transfusiology, 1, 11-15 [in Russian].

3. Kan, V.K. (1997). Kholestaz: novoye v patogeneze, diagnostike i lechenii [Cholestasis: new in pathogenesis, diagnosis and treatment]. Rossiyskiy zhurnal gastroenterologii, gepatologii - Russian Journal of Gastroenterology, Hepatology, 7, 3, 25-29 [in Russian].

4. Volkova, M.A. (Ed.). (2001). Klinicheskaya onkogematologiya [Clinical hematology oncology]. Moscow: Meditsina [in Russian].

5. Mayyer, K.P. (2004). Gepatit i posledstviya gepatita [Hepatitis and the consequences of hepatitis]. Transl. from Germ. Moscow: GEOTAR-Media [in Russian].

6. Exadaktylos, P., Reiss, T., Schobess, R., Hommann, M., Höhne, S., \& Beck, A. (1994). Acute hepatoxicity with intermediate-dose methotrexate inn children with leukemia and non-Hodgkin's lymphoma. Klin. Padiatr., 206 (4), 315-318. DOI: 10.1055/s-2008-1046622

7. Fowler, R., \& Imrie, K. (2001). Thalidomide-associated hepatitis: a case report. Am. J. Hematol., 66 (4), 300302. DOI: $10.1002 / a j h .1062$

8. Frezza, M., \& Terpin, M. (1992). The use of S-adenosyl-L-methiorline in the treatment of cholestatic disorders: a meta-analysis of clinical trials. Drug Invest., 4 (4), 101-108.

9. Hoebe, K.H., Witkamp, R.F., Fink-Gremmels, J., Van Miert, A.S., \& Monshouwer, M. (2001). Direct cell-tocell contact between Kupfer cells and hepatocytes augments endotoxin-induced hepatic injury. Am. J. Physiol. Gastrointest. Liver Physiol., 280 (4), G720-728. DOI: 10.1152/ajpgi.2001.280.4.G720
10. Jansen, P.L., \& Van der Lelie, H. (1994). Intrahepatic cholestasis and biliary cirrhosis associated with extrahepatic Hodgkin's disease. Neth. J. Med., 44 (3), 99102.

11. Vina, J. (Ed.). (1990). Glutathione metabolism and phisiological functions. Boston.

12. Levis, J.H., \& Schiff, E. (1998). Methotrexat-induced chronic liver injury: guidelines for detection and prevention. Am. J. Gastroenterol., 83 (12), 1337-1345.

13. Laidlaw, S.T., Reilly, J.T., \& Suarna, S.K. (1995). Fatal hepatotoxicity associated with 6-mercaptopurine therapy. Postgrad. Med. J., 71 (840), 639. DOI: 10.1136/ pgmj.71.840.639

14. Santini, D., Vincenzi, B., Massacesi, C., Picardi, A., Gentilucci, U.V., Esposito, V., \& Tonini, G. (2003). S-adenosylmethionine (AdoMet) supplementation for treatment of chemotherapy-induced liver injury. Anticancer Res., 23 (6D), 5173-5179.

15. Wang, L., Groves, M.J., Hepburn, M.D., \& Bowen, D.T. (2000). Glutathione-S-transferase enzyme expression in hematopoietic cell lines implies a differential protective role for $\mathrm{TI}$, and $\mathrm{Al}$ isoenzymes in erythroid and for $\mathrm{MI}$ in lymphoid lineages. Haematologica, 85 (6), 573-579.

16. Shano, V.P., \& Kucher, Ye.A. (2011). Sindrom endogennoy intoksikatsii [Syndrome of endogenous intoxication]. Ostryye i neotlozhnyye sostoyaniya v praktike vrachaAcute and Emergency Conditions in the Practice of a Doctor, 1 (25), 35-41 [in Russian].

17. Zhulkevych, I.V., Vybyrana, R.Y., \& Barannikov, K.V. (2013). Vikova dynamika zmin stanu mineralnoi shchilnosti kistkovoi tkanyny v khvorykh na khronichnu limfoidnu leikemiiu [Age dynamics of bone mineral density in patients with chronic lymphoid leukemia]. Visnyk naukovykh doslidzhen Bulletin of Scientific Research, 1, 47-50. DOI: https://doi. org/10.11603/2415-8798.2013.1.5700 [in Ukrainian].

\title{
ПРОФИЛАКТИКА И ЛЕЧЕНИЕ ТОКСИЧЕСКОГО ГЕПАТИТА И ЭНДОГЕННОЙ ИНТОКСИКАЦИИ У БОЛЬНЫХ ЛИМФОПРОЛИФЕРАТИВНЫМИ ЗАБОЛЕВАНИЯМИ
}

\section{ОЕ. Е. Самогальская, 3. П. Мандзий}

\author{
Тернопольский национальный медицинский университет имени И. Я. Горбачевского МОз Украины
}

РЕзЮМЕ. Согласно современным эпидемиологическим и статистическим исследованиям, совсем недавно в Украине отмечается значительное увеличение частоты случаев хронических заболеваний печени. Процесс сопровождается истощением системы антиоксидантной защиты, которое приводит к хронической интоксикации и метаболическим нарушениям, которые, в свою очередь, негативно влияют на функциональное состояние печени.

Цель - изучить эффективность применения комбинированного гепатопротектора «Гепаргин» в рамках комплексной терапии больных лимфопролиферативными заболеваниями.

Материал и методы. Под нашим наблюдением находились 42 больных лимфопролиферативными заболеваниями (6-с острыми лимфобластными лейкемиями; $16-$ с хронической лимфоидной лейкемией; 9-с неходжкинскими лимфомами; 7 - с неходжкинскими лимфомами из малых лимфоцитов и 5 пациентов с неходжкинскими лимфомами из больших гранулярных клеток). Возраст больных составил от 34 до 68 лет. Средняя продолжительность заболевания составляла 4-7 лет. Всем больным проводили УЗИ органов брюшной полости и определяли биохимические показатели функции печени, а именно аланинаминотрансферазы и аспартатаминотрансферазы, определяли билирубин, щелочную фосфатазу, тимоловую и сулемовую пробы, ядерный индекс интоксикации.

Результаты. Помимо жалоб основного заболевания (общая слабость, недомогание, тяжесть в нижних конечностях, головокружение) больных беспокоили тяжесть в правом подреберье, тошнота. Иногда отмечали желтизну кожи и слизистых оболочек. При УзИ обследовании печени у 22 больных отмечали увеличение размеров печени. В среднем печень увеличена как за счет правой, так и левой долей. У 19 пациентов отмечали повышение 
Огляди літератури, оригінальні дослідження, погляд на проблему, випадок з практики, короткі повідомлення АлТ и АСТ, у 11 больных также увеличение билирубина вследствие непрямой фракции. Процесс активности заболевания главным образом отвечал $(58,7$ \%) средней тяжести заболевания и $(21,3$ \%) тяжелой степени. В процессе как моно-, так и полихимиотерапии выраженность токсических эффектов на функцию гепатоцитов увеличивалась. Таким образом показатели АЛТ и АСТ увеличивались, отмечали повышение щелочной фосфатазы, билирубина, в основном непрямой фракции, показатели ядерного индекса интоксикации были повышены. У 5 больных с гемобластозами отмечали желтизну склер и кожи.

Выводы. На основе комплексного лечения с использованием препарата «Гепаргин» отмечали положительную динамику клинического течения основного заболевания. При этом отмечали общее состояние пациента, исчезновение ощущения тяжести в правом подреберье. Анализ показателей функциональных проб печени под влиянием терапии показал снижение активности воспалительного процесса в гепатоцитах. Улучшились показатели АЛТ, АСТ, билирубина, щелочной фосфатазы, яИИ.

у больных с минимальной и средней активностью заболевания эти показатели возвращались к нормальным значениям, а у больных с выраженной активностью процесса эти показатели значительно улучшались. Отмечали положительное влияние препарата на белковый обмен, о чем свидетельствует нормализация общего белка сыворотки крови.

КЛЮчЕВЫЕ СЛОВА: гепаргин; лейкемии; токсический гепатит; эндогенная интоксикация.

\section{PREVENTION AND TREATMENT OF TOXIC HEPATITIS AND ENDOGENOUS INTOXICATION IN PATIENTS WITH LYMPHOPROLIFERATIVE DISEASES

\author{
๑O. Ye. Samohalska, Z. P. Mandzii \\ I. Horbachevsky Ternopil National Medical University
}

SUMMARY. According to the modern epidemiological and statistical studies, recently, in Ukraine, a significant increase in the incidence rate of chronic liver disease was noted. The course is accompanied by the exhaustion of the antioxidant system against to the background of chronic intoxication with metabolic disorders that adversely affect the functional state of the liver.

The aim - is to study the effectiveness of the combined hepatoprotector "Hepargin" as part of complex therapy in patients with hemoblastomas.

Material and Methods. We observed 42 patients with hemoblastomas (6 - with acute lymphoblastic leukemias; 16 - with chronic lymphoid leukemias; 9 - with non-Hodgkin's lymphomas: 7 - with non-Hodgkin's lymphomas from small lymphocytes, and 5 patients - with non-Hodgkin's lymphomas from large granular cells), aged 34-68 years. The average duration of the disease was 4-7 years. All patients underwent ultrasound examination of the abdominal cavity (ultrasound examination) and biochemical parameters of the liver function, namely, alanine aminotransferase, aspartate aminotransferase, bilirubin, alkaline phosphatase, timolol and sulam samples.

Results. In addition to complaints of the underlying disease (which is general weakness, anomalies, heaviness in the lower extremities, dizziness, mischief), the patients were concerned about the severity and sensation of dislocation in the right hypochondrium, nausea. Occasionally, jaundice of the skin and mucous membranes was observed. With ultrasound examination in 17 patients, an increase in liver size was observed. The liver was enlarged at the expense of both particles. In 27 patients, there was an increase in ALT and AST, and in 11 patients, increased bilirubin was observed due to an indirect fraction. The activity of the process mostly corresponded to an average of $58.7 \%$, and a pronounced $21.3 \%$ degree. In the process of obtaining both mono and polychemotherapy, the activity of the severity of toxic effects on the state of hepatocyte function increased, as indicated by an increase in liver samples. Thus, ALT and AST elevations were observed, as well as an increase in alkaline phosphatase, bilirubin due to an indirect fraction.

KEY WORDS: hepargin; leukemia; treatment; toxic hepatitis; endogenous intoxication. 